\title{
Determination of Nitrofurazone in Topical Pharmaceutical Preparations: Comparison of the UV-Visible Diffuse Reflectance versus Transmittance versus HPLC Methods
}

\author{
Matthieu Tubino, ${ }^{*, a}$ Marta Maria D. C. Vila ${ }^{b}$ and Marcio N. Palumbo ${ }^{a}$ \\ ${ }^{a}$ Instituto de Química, Universidade Estadual de Campinas, CP 6154, \\ 13083-970 Campinas-SP, Brazil \\ ${ }^{b}$ Universidade de Sorocaba, Rod. Raposo Tavares, km 92.5, 13023-000 Sorocaba-SP, Brazil
}

\begin{abstract}
A técnica HPLC tem tido importante aplicação na análise de princípios ativos em preparações farmacêuticas. Algumas vezes, contudo, o uso desta técnica que, presumivelmente é mais rápida, simples e confiável, não é o mais indicado. Em vários casos, métodos mais simples e rápidos oferecem evidentes vantagens. Neste trabalho, foi feita a comparação dos resultados obtidos pelo método recomendado, HPLC, com aqueles obtidos por refletância difusa no UV-Visível e, também, com medidas clássicas de transmitância. Os resultados experimentais foram comparados entre si usando o procedimento estatístico pareado de Student, tendo sido observada total concordância entre eles em nível de confiança de $95 \%$. Entre os métodos usados, o de refletância difusa apresenta a maior simplicidade operacional. O de transmitância apresenta a maior precisão. A exatidão dos três métodos é similar. Uma característica interessante do método refletométrico proposto é que, apesar de ser quantitativo, não é necessário pesar as alíquotas das preparações farmacêuticas para o procedimento analítico.
\end{abstract}

HLPC has been an important technique in the analysis of pharmaceutical principles in pharmaceutical preparations. Sometimes, however, the use of this technique presumed to be more rapid, simple and reliable, is not the most adequate. In various cases simpler and more rapid methods can be used with clear advantages. In the present work the comparison of the quantitative results obtained with the HPLC recommended method with those resulted from the UV-Visible diffuse reflectance determination procedure and with the classical transmittance measurements of aqueous solutions was done. The experimental results of the three methods were compared through the statistical Student's $\boldsymbol{t}$ test and agreement was observed at 95\% confidence level. Among them the diffuse UV-Visible reflectance procedure is the simplest and the transmittance method offered the highest precision. The accuracy of the three methods is similar. A very interesting characteristic of the proposed reflectance method is that, despite the fact that it is quantitative, no weighing of aliquots is needed.

Keywords: diffuse reflectance, ultraviolet, visible, quantitative analysis, nitrofurazone

\section{Introduction}

Nitrofuranes are substances that contain a nitroso group in the position 5 of the furane ring. They present antibacterial, antifungal and anti protozoa activity. Nitrofurazone, 2-[(5-nitro-2-furanyl)methylene] hydrazine carboxamide, was the first nitrofuranic derivative introduced in the medical clinic in 1946 for oral treatment of bacterial infections and for the treatment of the Chagas

\footnotetext{
*e-mail: tubino@iqm.unicamp.br
}

disease. However, serious toxic effects were observed and in the Chagas disease the therapeutic results were unsatisfactory. ${ }^{1}$ Therefore, nitrofurazone is used today in topical treatments. It presents wide action spectrum against gram-positive and gram-negative organisms. Its disinfectant activity favors the cicatrization of wounds produced by traumatisms, burns and surgical procedures. It can also be used for the treatment of bacterial infections caused by epidemic infections in hospitals, piodermic infections and cutaneous ulcers. ${ }^{2}$ However its action mechanism is not clearly understood. 
The molecular formula of nitrofurazone is $\mathrm{C}_{6} \mathrm{H}_{6} \mathrm{~N}_{4} \mathrm{O}_{4}$ (molar weight $198.136 \mathrm{~g} \mathrm{~mol}^{-1}$ ) and its structural formula is shown in Figure 1. It presents as characteristics: yellow color $\left(\lambda_{\max }=375 \mathrm{~nm}\right)$; no odor; and is very slightly soluble in water $(1: 4200))^{3-5}$

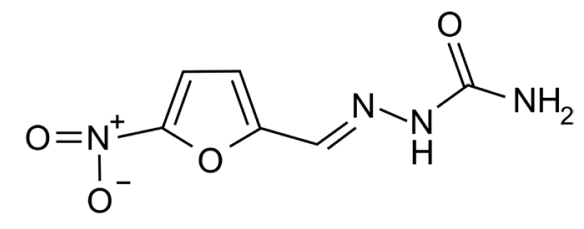

Figure 1. Structural formula of nitrofurazone.

The pharmaceutical preparations available in the market are in the form of solutions or ointments for topical use, containing $0.2 \% \mathrm{~m} / \mathrm{m}$ of nitrofurazone. ${ }^{6}$

Various methods are described in the literature for the analysis of nitrofurazone in bulk material and in pharmaceutical

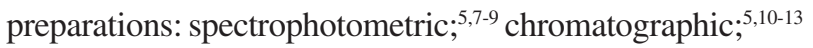
voltametric; $;{ }^{14-17}$ quimioluminescence; ${ }^{18}$ fluorescence. ${ }^{19}$ In the recommended spectrophotometric method ${ }^{5}$ for the determination of nitrofurazone in the pure drug it is necessary to dissolve the sample in dimethylformamide and dilute with water. The absorbance measurements are done at $375 \mathrm{~nm}$. For ointments an HPLC procedure was recommended. ${ }^{5}$

Agrawal and Patel $^{7}$ developed a method where nitrofurazone reacts with hydroxymetilamine in alkaline medium yielding hydroxamic acid, following reaction of this acid with iron(III) ions forming a violet purple color complex.

Sastry et al. ${ }^{8}$ proposed four spectrophotometric methods based on the formation of colored species. The first concerns to the determination of a product formed by the reduction of the nitrofurazone with 3-methylbenzothiazolin-2-one hydrazone (MBTH) in presence of iron(III) chloride $\left(\lambda_{\max }=600 \mathrm{~nm}\right)$. The second and the third methods employ the reaction of the nitrofurazone hydrolysis product with thiobarbituric $\left(\lambda_{\max }=520 \mathrm{~nm}, 440 \mathrm{~nm}\right)$ acid and with barbituric acid $\left(\lambda_{\max }=440 \mathrm{~nm}\right)$. The other method implies in the oxidation of nitrofurazone with excess of N-bromosuccinimide (NBS) and determines the consumed NBS using metol-isonicotinic acid hydrazide $\left(\lambda_{\text {max }}=620 \mathrm{~nm}\right)$.

A simple colorimetric method for the determination of six nitro derivatives, namely, furazolidone, nifuroxime, niridazole, nitrazepam, nitrofurantoin and nitrofurazone, was described by Walash et al. ${ }^{9}$ The suggested method depends upon the formation of orange to purple color when these nitro compounds react with tetrabutylammonium hydroxide in dimethylformamide.

The method recommended for the determination of nitrofurazone in topic pharmaceutical preparations (ointments) is HPLC. In this procedure organic solvents are used and filtering in a nylon $0.5 \mu \mathrm{m}$ porosity filter must be done. More than 35 min of manipulation are necessary. ${ }^{5}$

The chromatography on paper was employed by Shajahan and co-workers ${ }^{10,11}$ for the separation of other substances. However for the quantitative determination, the extraction of the nitrofurazone with organic solvent from the paper is necessary. After the extraction the determination of the absorbance is done at $375 \mathrm{~nm}$. Voltametric methods have also been related. ${ }^{14-17}$ These methods however are very sensitive to interferences.

The fluorescence method described by Belal, ${ }^{19} \mathrm{can}$ be applied for the analysis of various nitrofuran drugs. Nitrofurazone, dissolved in dimethylformamide, is determined at $445 \mathrm{~nm}\left(\lambda_{\text {exc }}=245 \mathrm{~nm}\right)$. The analytical signal is linear from $4 \times 10^{-3}$ to $5 \times 10^{-2} \mu \mathrm{g} \mathrm{mL}^{-1}$.

The development of simple and rapid analytical methods is always interesting. The diffuse reflectance spectroscopy in the ultraviolet and visible region of the spectrum frequently allows the direct quantitative analysis of analytes with the minimum of treatment, with consequent decrease in the manipulation and in the use of organic solvents and chemical reagents. ${ }^{20-25}$

The aim of the present work was essentially to develop a very simple UV-Visible diffuse reflectance analytical method for the determination of nitrofurazone, a yellow compound, in pharmaceutical preparations and to compare its performance with HPLC, the USP method, ${ }^{5}$ and also with a transmittance procedure. This analyte was selected because its color permits direct colorimetric measurements, avoiding the necessity of chemical reactions to develop adequate light absorbing chemical species. This characteristic allows direct comparison of the three different studied methods.

\section{Experimental}

\section{Chemicals}

All the reagents and solvents used were of analytical grade except nitrofurazone, a pharmaceutical certified product (99.0\%) gently furnished by Mantecorp Indústria Química e Farmacêutica Ltda. Water was of bidistilled grade, obtained in a glass distillator. In all cases the nitrofurazone content in the pharmaceutical product was taken into account for the calculus of the concentration.

\section{Apparatus}

HPLC: Shimadzu Prominence with diode array SPP-M20; column $\mu$ Bondapac C18, length $300 \mathrm{~mm}$, I.D. $3.9 \mathrm{~mm}$, particle size $10 \mu \mathrm{m}, \varnothing 125$ angstroms. 
Spectrophotometer: Ultraviolet Visible Shimadzu UV-2450 spectrophotometer equipped with a reflectance accessory. Home made reflectometer: The home made reflectometer had already been described in details ${ }^{26}$ and in this article is shown in Figure2. In the present case a blue E1L31-3G0A2 Toyoda Gosei Co. Ltd. LED was used: $\varnothing 3$ mm E.D.; view angle 15 degrees.

\section{Calibration curves and samples treatment}

For the construction of the calibration curves for all the methods, nitrofurazone standard solutions in polyethylene glycol (degree of polymerization $4 \times 10^{4}$ ) were prepared by weighing them in an analytical balance, the analyte and the solvent, into a $50 \mathrm{~mL}$ beaker ( $\mathrm{m} / \mathrm{m}$ solutions). Mixture was heated in an oven at $60{ }^{\circ} \mathrm{C}$ during $5 \mathrm{~min}$. After the melting the homogenization of the resulting solution was easily done with a glass rod. By cooling the solutions they acquired the aspect of an ointment.

As the pharmaceutical preparations were ointments it was supposed that they were homogeneous enough and no further homogenization was performed. Also, as their nominal concentration was $2 \mathrm{mg} \mathrm{g}^{-1}$ no dilution was necessary because the method allows direct measurements at this order of concentration.

For the reflectance method no special preparation other than heating to $60^{\circ} \mathrm{C}$ the sample placed on the butter paper was necessary. The experimental conditions were adjusted in order to allow direct analysis of the ointments without further treatment. For the transmittance method aliquots of the samples were dissolved in water in order to obtain concentration in the range from $6 \times 10^{-3} \mathrm{mg} \mathrm{g}^{-1}$ to $10 \times 10^{-3} \mathrm{mg} \mathrm{g}^{-1}$ of nitrofurazone. For the HPLC method the procedure followed the USP recommendations. ${ }^{5}$

\section{Transmittance method}

For the construction of the calibration curve and also in the case of the samples, nitrofurazone, or the commercial ointment, were dissolved in polyethylene glycol. This solution can be easily diluted with water, giving water solutions of nitrofurazone, compound slightly soluble in water. Therefore, initially, solutions of known concentrations of the analyte in polyethylene glycol were prepared. In a balance, aliquots of these nitrofurazone polyethylene glycol solutions, carefully weighed in a $50 \mathrm{~mL}$ beaker, were diluted adding water, in order to obtain the adequate weight/weight concentrations in $\mathrm{mg}$ of the solute per gram of the solution. The standard solutions were prepared by weight according to the procedure described above; a calibration curve was obtained from $2.0 \times 10^{-3} \mathrm{mg}$ $\mathrm{g}^{-1}$ to $14 \times 10^{-3} \mathrm{mg} \mathrm{g}^{-1}$. Absorbance was measured at $375 \mathrm{~nm}$, using quartz cells of $1.00 \mathrm{~cm}$ of optical path.

\section{HPLC method}

Triethylamine buffer: ${ }^{5} 100 \mathrm{~mL}$ of this organic solvent were put in a $1000 \mathrm{~mL}$ volumetric flask. In sequence
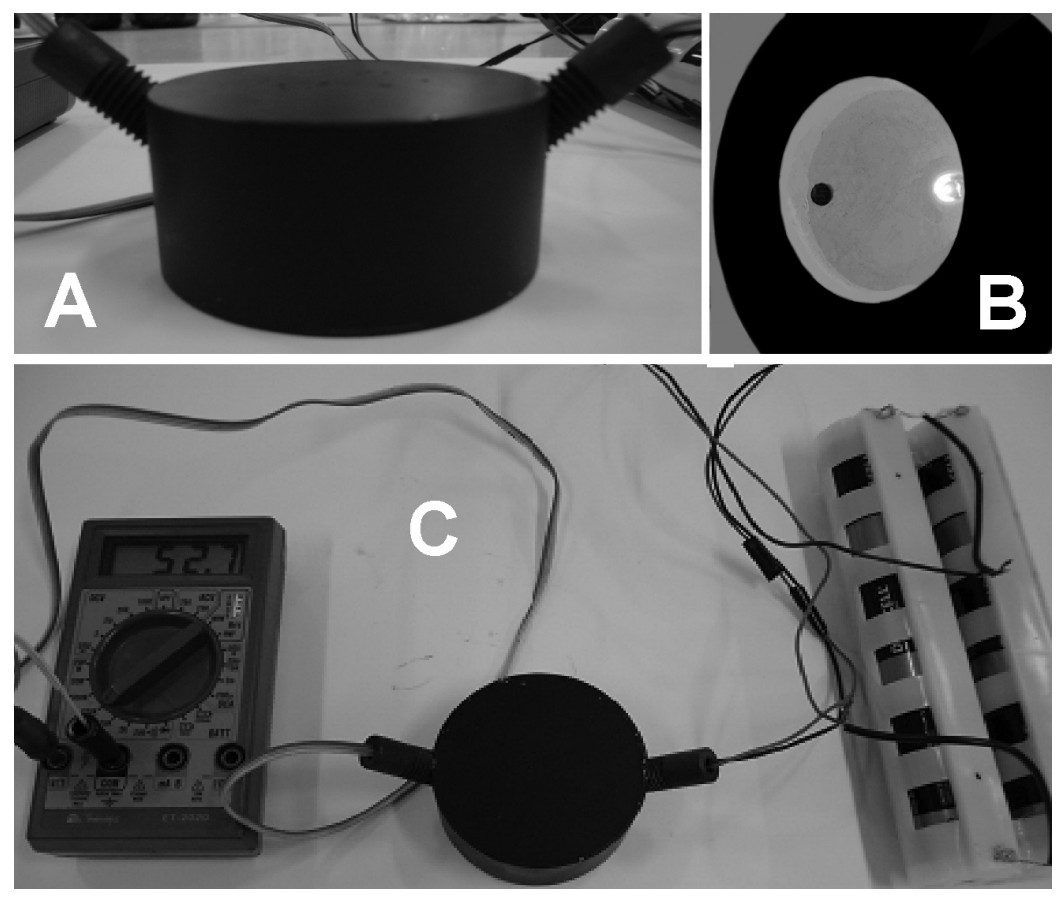

Figure 2. The reflectometer made in the laboratory: A - general external view; B - under view showing the reflecting chamber, the LED (light emitter diode) and the LDR (light dependent resistor); $\mathrm{C}$ - The reflectometer connected to the multimeter, measuring resistance in Ohm, and to the power source (six $1.5 \mathrm{~V}$ batteries). 
$800 \mathrm{~mL}$ of cool water were added. After homogenization, to this solution $80 \mathrm{~mL}$ of concentrated phosphoric acid was carefully added under constant stirring. After the solution has attained the ambient temperature $\left(25^{\circ} \mathrm{C}\right)$ the volume was completed to the mark and the solution was filtered through a $0.5 \mu \mathrm{m}$ porosity nylon filter.

Standard solution of nitrofurazone: Solution of nitrofurazone was prepared in the following way. $50.0 \mathrm{mg}$ of the nitrofurazone was dissolved in a $50.0 \mathrm{~mL}$ volumetric flask with $10.0 \mathrm{~mL}$ of dimethylformamide. The volume was completed to the mark with ethanol. $10.0 \mathrm{~mL}$ of this solution were transferred to a $100.0 \mathrm{~mL}$ volumetric flask completing the volume with ethanol. $10.0 \mathrm{~mL}$ of this solution were transferred to a $100.0 \mathrm{~mL}$ volumetric flask containing $15.0 \mathrm{~mL}$ of ethanol and the volume was completed with water. This solution was filtered through a $0.5 \mu \mathrm{m}$ porosity nylon filter and used as recommended. This solution contained $11.3 \times 10^{-3} \mathrm{mg} \mathrm{g}^{-1}$ of nitrofurazone. In order to compare more adequately the HPLC performance in relation to the other two methods, a calibration curve was constructed preparing standard nitrofurazone ointments: $4.43 \times 10^{-3}, 7.12 \times 10^{-3}$, $8.56 \times 10^{-3}, 12.1 \times 10^{-3}, 12.7 \times 10^{-3}, 13.6 \times 10^{-3}, 13.7 \times 10^{-3} \mathrm{mg} \mathrm{g}^{-1}$. The solution containing $11.3 \times 10^{-3} \mathrm{mg} \mathrm{g}^{-1}$ of nitrofurazone prepared according to USP recommendation was introduced into this standard series.

Samples treatment: aliquots of the pharmaceutical preparation containing about $1 \mathrm{mg}$ of nitrofurazone, exactly weighed in an analytical balance, were quantitatively transferred to a $100.0 \mathrm{~mL}$ volumetric flask. In sequence $0.2 \mathrm{~mL}$ of dimethylformamide and $25 \mathrm{~mL}$ of ethanol were added. These mixtures were treated with ultrasound for $30 \mathrm{~min}$. The volume was completed with water and the final solutions were filtered through a $0.5 \mu \mathrm{m}$ porosity nylon filter. Chromatographic conditions: an octadecylsilane column of $10 \mu \mathrm{m}$ particle size diameter was used. The mobile phase was constituted by a solution containing water, acetonitrile and triethylamine buffer in the 790:200:10 proportion v/v/v. The flow rate was $2 \mathrm{~mL}$ $\mathrm{min}^{-1}$. The injection volume was $20 \mu \mathrm{L}$ and the elution time about $8 \mathrm{~min}$. Detection was done at $365 \mathrm{~nm}$.

\section{Diffuse reflectance method}

The calibration curve was constructed by preparing solutions of nitrofurazone in polyethylene glycol according to the procedure described above, from $1.00 \mathrm{mg} \mathrm{g}^{-1}$ to $2.98 \mathrm{mg} \mathrm{g}^{-1}$, dissolving the adequate amount of the analyte in $20.00 \mathrm{~g}$ of polyethylene glycol. The absorbances were measured at $385 \mathrm{~nm}$. The nitrofurazone solutions were put on the support (butter paper) without necessity of weighing: a quantity of the ointment was placed on a folded paper (Figure 3A). The two parts were closed, followed by a heating for $5 \mathrm{~min}$ at $60{ }^{\circ} \mathrm{C}$ in an oven. In sequence, opening the paper, the excess of the ointment was removed manually with absorbent paper, for example, toilet paper. A foil of black PVC (polyvinyl chloride) was put between the two parts of the paper (Figure 3B) and the absorbance of the diffuse reflectance process was determined at $385 \mathrm{~nm}$ in the Shimadzu spectrophotometer (Figure 3C) or in the portable device constructed in our laboratory using a blue light emitter diode according to the instrument described by Matias et $a l .{ }^{26}$ In this manual reflectometer, to do the measurements, it is enough to place them on the paper containing the analyte.

\section{Results and Discussion}

In diffuse reflectance procedure several supports were tested, including a variety of papers and polymers.
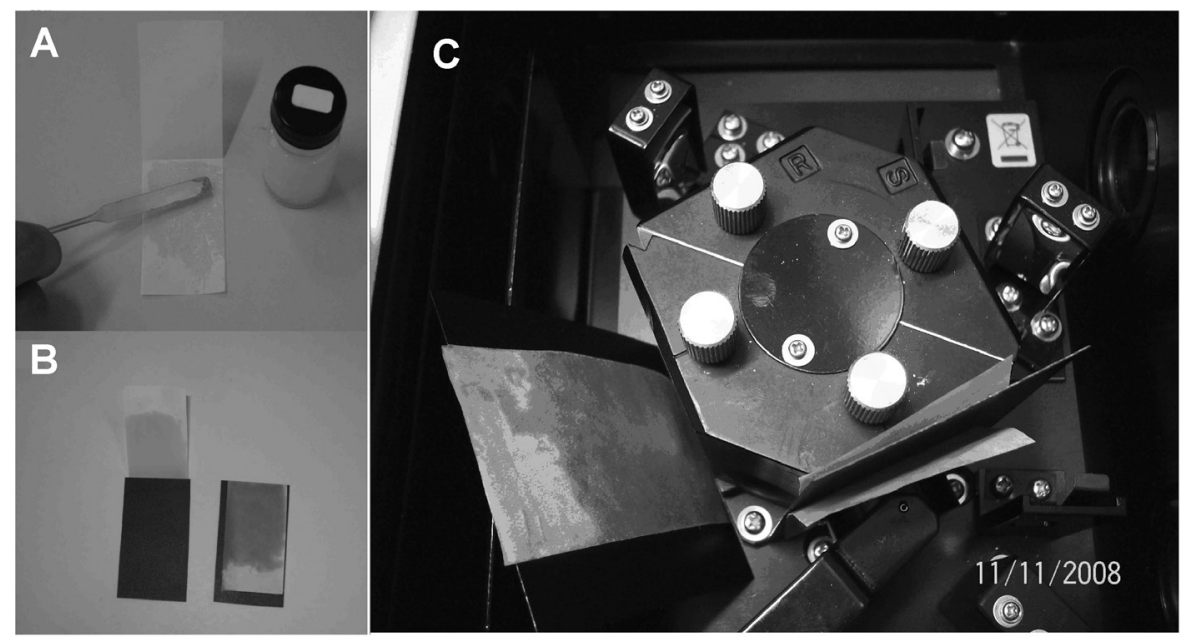

Figure 3. Preparation of a sample for diffuse reflectance measurement: A- placement of the ointment on the butter paper; B- introduction of a black PVC foil between the folded paper; C- introduction of the sample in the reflectometric accessory of the Shimadzu UV-2450 spectrophotometer. 
Promising results were obtained with different qualities of paper, including qualitative and quantitative filter papers and also chromatographic papers. Surprisingly however, the best experimental results were obtained with butter paper purchased in the local market. It is important to note that the intention was to develop a method that could offer quantitative results directly with the samples without dilutions or other procedures than to put the aliquot on the paper. It is very interesting to note that in the reflectometric procedure weighing of aliquots is unnecessary. This fact can be easily understood as the quantity of the analyte is determined by the dimensions of the surface on which the reflectance occurs. If the analyte is always homogeneously distributed on the paper, the analytical signal will be proportional to its concentration.

The calibration curve obtained with butter paper, and the Shimadzu spectrophotometer, is described by the first order equation $\mathrm{A}=0.1006+0.05067 \mathrm{C}$, where $\mathrm{C}$ is the concentration of nitrofurazone in milligram per gram of the solution (ointment) and $\mathrm{A}$ is the measured absorbance (reflectance process) at $385 \mathrm{~nm}$. The coefficient of correlation is $r=0.9978$; limit of detection, LOD $c a .0 .25 \mathrm{mg} \mathrm{g}^{-1}$; limit of quantitation, LOQ ca. $0.75 \mathrm{mg} \mathrm{g}^{-1}$.

With the reflectometer made in the laboratory ${ }^{26-28}$ the analytical curve obtained was described by the following equation: $\rho=106.0+8.912 \mathrm{C}(\mathrm{r}=0.9995)$. $\rho$ is the resistance in ohms of the detector, a light dependent resistor (LED), and $\mathrm{C}$ is the nitrofurazone concentration in $\mathrm{mg} \mathrm{g}^{-1}$; LOD $c a .0 .35 \mathrm{mg} \mathrm{g}^{-1}$; LOQ $c a .1 .1 \mathrm{mg} \mathrm{g}^{-1}$.

The calibration curve for the transmittance procedure was obtained from $2 \times 10^{-3} \mathrm{mg} \mathrm{g}^{-1}$ to $14 \times 10^{-3} \mathrm{mg} \mathrm{g}^{-1}$ measured at $385 \mathrm{~nm}$, with absorbance values from 0.1 to 1.0. This analytical curve is described by the equation $\mathrm{A}=-0.01674+0.07818 \mathrm{C}$, where $\mathrm{C}$ is the concentration of nitrofurazone in milligram per gram of the solution and A is the measured absorbance at $375 \mathrm{~nm}$. The coefficient of correlation is $\mathrm{r}=0.9998$; LOD $c a .0 .37 \times 10^{-3} \mathrm{mg} \mathrm{g}^{-1}$; LOQ $c a .1 .1 \times 10^{-3} \mathrm{mg} \mathrm{g}^{-1}$.

Normally nitrofurazone is not soluble in water. However, when it is initially dissolved in polyethylene glycol, of any degree of polymerization, the dilution of these solutions in water is possible. The subsequent obtained solutions are stable for, at least, $72 \mathrm{~h}$ at room temperature $\left(c a .25{ }^{\circ} \mathrm{C}\right)$, precipitating nitrofurazone beyond this time.

In the HPLC method the calibration curve was constructed from $4.3 \times 10^{-3} \mathrm{mg} \mathrm{g}^{-1}$ to $13.8 \times 10^{-3} \mathrm{mg} \mathrm{g}^{-1}$. This curve is described by the equation $\mathrm{Ar}=-16693+8.6665 \times 10^{7} \mathrm{C}$, where $\mathrm{C}$ is the concentration of nitrofurazone in $\mathrm{mg} \mathrm{g}^{-1}$ of the solution and Ar is the area of the analytical signal. The coefficient of correlation is $\mathrm{r}=0.9962$; LOD $c a$. $0.41 \times 10^{-3} \mathrm{mg} \mathrm{g}^{-1}$; LOQ $c a .1 .2 \times 10^{-3} \mathrm{mg} \mathrm{g}^{-1}$.

From the correlation coefficients obtained it is evident that the transmittance method is the most precise and the two reflectance and the HPLC methods have similar precision. It is interesting to observe that even the home made reflectometer gave analytical results as good as those obtained with the HPLC method. Due to the operational simplicity, the time consumed and the fact that no organic hazardous solvents are used in the reflectometric methods, it can be considered that the method presents significant advantages over the HPLC procedure in the present case.

In Table 1, the results obtained with the three methods are presented. Statistical comparison was done using the Student's $t$-test and the F-test. ${ }^{29}$ Complete agreement among the three methods in terms of the $\boldsymbol{t}$-test method was observed. A small difference is observed, in three cases, between the transmittance and the HPLC methods, in relation to the precision as the calculated $\mathbf{F}$ values are a little higher than the tabulated value, as the former method is about four times more precise than the last.

In Figure 4 the reflectance absorption spectrum and the spectrum obtained in solution by transmission of light are presented. Despite the difference in the concentration level, the similarity of the spectra is obvious with a displacement of $10 \mathrm{~nm}$ of the maximum absorption peak from $375 \mathrm{~nm}$ (transmittance) to $385 \mathrm{~nm}$ (reflectance). From the transmission spectrum, molar absorptivity can be estimated for the aqueous solution at $375 \mathrm{~nm}$ as about $8.4 \times 10^{3} \mathrm{~L} \mathrm{~mol}^{-1} \mathrm{~cm}^{-1}$. If in an analogous procedure, the absorption of the reflectance procedure is considered per $\mathrm{cm}^{2}$ and per mol of the substance in the polyethylene glycol solution, a molar absorptivity can be estimated for nitrofurazone at $385 \mathrm{~nm}: 1.5 \times 10^{4} \mathrm{~g} \mathrm{~mol}^{-1} \mathrm{~cm}^{-2}$.

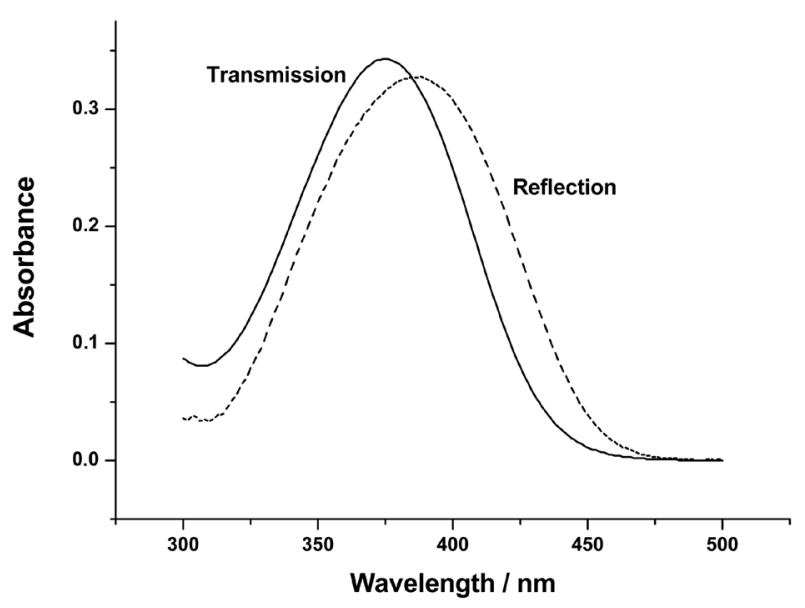

Figure 4. Transmittance (aqueous solution $8.28 \times 10^{-3} \mathrm{mg} \mathrm{g}^{-1}$ ) and reflectance (ethylene glycol ointment $3.00 \mathrm{mg} \mathrm{g}^{-1}$ ) spectra of nitrofurazone from 300 to $500 \mathrm{~nm}$. 
Table 1. Determination of nitrofurazone in ointments: Comparison among the values obtained by diffuse reflectance, transmittance and HPLC methods using the statistical Student's $\boldsymbol{t}$-test and the F-test. Tabulated $\boldsymbol{t}$ value for the degree of freedom ( $v) 4$ is $2.78(\alpha=0.05), v=\mathrm{n}_{1}+\mathrm{n}_{2}-2$ and $\mathrm{n}_{1}=\mathrm{n}_{2}=3$ in this instance. $\mathbf{F}$ tabulated value is $19.0(\alpha=0.05){ }^{29}$

\begin{tabular}{|c|c|c|c|c|c|c|c|c|c|c|c|c|}
\hline \multirow[b]{2}{*}{ Sample } & \multicolumn{3}{|c|}{ Reflectance I ${ }^{\mathrm{a}}$} & \multicolumn{3}{|c|}{ Reflectance $\mathrm{II}^{\mathrm{b}}$} & \multicolumn{3}{|c|}{ Transmittance } & \multicolumn{3}{|c|}{ HPLC } \\
\hline & $\begin{array}{l}\text { Conc. }^{\mathrm{c}} / \\
\left(\mathrm{mg} \mathrm{g}^{-1}\right)\end{array}$ & SD & RSD / \% & $\begin{array}{l}\text { Conc. }^{\mathrm{c}} / \\
\left(\mathrm{mg} \mathrm{g}^{-1}\right)\end{array}$ & SD & RSD / \% & $\begin{array}{l}\text { Conc. }^{\mathrm{c}} / \\
\left(\mathrm{mg} \mathrm{g}^{-1}\right)\end{array}$ & SD & RSD / \% & $\begin{array}{l}\text { Conc. }^{\mathrm{c}} / \\
\left(\mathrm{mg} \mathrm{g}^{-1}\right)\end{array}$ & SD & $\mathrm{RSD} / \%$ \\
\hline $\mathrm{A} 712^{\mathrm{d}}$ & 2.16 & \pm 0.10 & 4.6 & 2.16 & \pm 0.17 & 7.9 & 2.16 & \pm 0.03 & 1.4 & 2.21 & \pm 0.10 & 4.5 \\
\hline $\mathrm{A} 720^{\mathrm{d}}$ & 2.12 & \pm 0.08 & 3.8 & 2.15 & \pm 0.08 & 3.7 & 2.15 & \pm 0.02 & 0.9 & 2.16 & \pm 0.09 & 4.2 \\
\hline$A 726^{d}$ & 2.14 & \pm 0.08 & 3.7 & 2.17 & \pm 0.07 & 3.2 & 2.18 & \pm 0.02 & 0.9 & 2.05 & \pm 0.09 & 4.4 \\
\hline $\mathrm{A} 728^{\mathrm{d}}$ & 2.20 & \pm 0.08 & 3.6 & 2.18 & \pm 0.13 & 6.0 & 2.21 & \pm 0.02 & 0.9 & 2.16 & \pm 0.10 & 4.6 \\
\hline B78932e & 2.02 & \pm 0.08 & 4.0 & 2.15 & \pm 0.11 & 5.1 & 2.15 & \pm 0.02 & 0.9 & 2.05 & \pm 0.09 & 4.4 \\
\hline \multicolumn{3}{|c|}{ Mean RSD \% } & 3.9 & & & 5.2 & & & \multicolumn{2}{|l|}{1.0} & & 4.4 \\
\hline \multirow[t]{2}{*}{ Sample } & \multicolumn{2}{|c|}{ Reflec I / Reflec II } & \multicolumn{2}{|c|}{ Reflec I / Trans } & \multicolumn{2}{|c|}{ Reflec II / Trans } & \multicolumn{2}{|c|}{ Reflec I / HPLC } & \multicolumn{2}{|c|}{ Reflec II / HPLC } & \multicolumn{2}{|c|}{ Trans / HPLC } \\
\hline & $\boldsymbol{t}_{\text {calc }}$ & $\mathbf{F}_{\text {calc }}$ & $\boldsymbol{t}_{\text {calc }}$ & $\mathbf{F}_{\text {calc }}$ & $\boldsymbol{t}_{\text {calc }}$ & $\mathbf{F}_{\text {calc }}$ & $\boldsymbol{t}_{\text {calc }}$ & $\mathbf{F}_{\text {calc }}$ & $\boldsymbol{t}_{\text {calc }}$ & $\mathbf{F}_{\text {calc }}$ & $\boldsymbol{t}_{\text {calc }}$ & $\mathbf{F}_{\text {calc }}$ \\
\hline $\mathrm{A} 712^{\mathrm{d}}$ & 0.00 & 2.89 & 0.00 & 11.1 & 0.00 & 32.1 & 0.83 & 1.00 & 0.44 & 2.89 & 0.85 & 1.00 \\
\hline $\mathrm{A} 720^{\mathrm{d}}$ & 0.05 & 1.00 & 0.54 & 16.0 & 0.00 & 16.0 & 0.58 & 1.27 & 0.14 & 1.26 & 0.17 & 11.1 \\
\hline $\mathrm{A} 726^{\mathrm{d}}$ & 0.05 & 1.31 & 0.71 & 16.0 & 0.24 & 12.3 & 1.30 & 1.27 & 1.82 & 1.65 & 2.48 & 20.3 \\
\hline $\mathrm{A} 728^{\mathrm{d}}$ & 0.23 & 2.64 & 0.17 & 16.0 & 0.40 & 42.3 & 0.54 & 1.56 & 0.21 & 1.69 & 0.86 & 25.0 \\
\hline B78932e & 1.48 & 1.89 & 2.32 & 16.0 & 0.00 & 30.2 & 0.43 & 1.27 & 1.22 & 1.49 & 1.63 & 20.3 \\
\hline
\end{tabular}

${ }^{\mathrm{a}}$ Diffuse reflectance: Shimadzu UV-2450 with diffuse reflectance accessory. ${ }^{\mathrm{b}}$ Diffuse reflectance: Simple device. ${ }^{26 \mathrm{c}}$ Nominal concentration $=2.0 \mathrm{mg} \mathrm{g}^{-1}$.

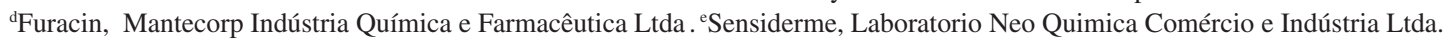

\section{Conclusions}

The study carried out in this work shows clearly that the three studied methods can be used for the determination of nitrofurazone in pharmaceutical ointments as they present adequate accuracies. However, the transmittance method is about four times more precise than the other two. The reflectance method presents a similar precision to that of HPLC. In relation to the procedures, the reflectance method is the simplest and the HPLC, with no doubt, is the less simple. In this case, also organic solvents are used. The transmittance method described in this work uses polyethylene glycol to dissolve nitrofurazone but in sequence only water is used. The reflectance method has an additional advantage over the transmittance one because aliquot weighing of the samples is unnecessary as the analysis is done directly in the original matrix without dilution. Undoubtedly, the HPLC procedure is the most sluggish and difficult among the three and the reflectometric the simplest one.

Based on the observed results the reflectance and the transmittance methods developed in this work can be suggested for the determination of nitrofurazone in pharmaceutical ointments as they present operational simplicity, rapidity, enough accuracy and precision. The results clearly reinforced the idea that, in some cases, simpler, rapid, reliable and cheaper quantitative analytical methods, other than HPLC, and particularly spectrophotometric procedures, can be developed and used for the quantitative analysis of several analytes in some analytical matrixes, particularly in the case of pharmaceuticals.

\section{Acknowledgments}

The authors are grateful to CAPES, Coordenação de Aperfeiçoamento de Pessoal de Nível Superior, to CNPq, Conselho Nacional de Pesquisa Científica e Tecnológica, and to FAPESP, Fundação de Amparo à Pesquisa do Estado de São Paulo, for the financial support.

\section{References}

1. Tavares, W.; Manual de Antibióticos e Quimioterápicos Antiinfecciosos, Atheneu: São Paulo, SP, Brasil, 2001.

2. Hardman, J. G.; Limbird, L. E; Goodman e Gilman: As Bases Farmacológicas da Terapêutica, $10^{\text {th }}$ ed., Guanabara Koogan: Rio de Janeiro, RJ, Brasil, 2003.

3. The Merck Index: An Encyclopedia of Chemicals, Drugs and Biologicals, 14 ${ }^{\text {th }}$ ed., Merck \& Co: Whitehouse Station NJ, 2006.

4. Kleemann, A.; Engel, J.; Kutscher, B.; Pharmaceutical Substances: Syntheses, Patents, Applications, $4^{\text {th }}$ ed., Thieme: Stuttgart, 2001.

5. The United States Pharmacopeia. The National Formulary; $28^{\text {th }}$ ed., Unites States Pharmacopeial Convention: Rockville, 2005. 
6. Faulkner, D. M.; Sutton, S. T.; Hesford, J. D.; Faulkner B. C.; Major, D. A.; Hellewell, T. B.; Laughon, M. M.; Rodeheaver, G. T.; Edlich, R. F.; Am. J. Emerg. Med. 1997, 15, 20.

7. Agrawal, Y. K.; Patel, D. R; Anal. Lett. 1986, 19, 1289.

8. Sastry, B. S.; Rao, J. V.; Rao, T. T.; Sastry, C. S. P.; Mikrochim. Acta 1992, 108, 185.

9. Walash, M. I.; El-Brashy, A. M.; Sultan, M. A.; Anal. Lett. 1993, 26, 499.

10. Shajahan, M.; Enever, R. P.; Int. J. Pharm. 1992, 82, 215.

11. Shajahan, M.; Shalaby, A.; Int. J. Pharm. 1998, 168, 169.

12. Lunn, G.; Methods for Pharmaceutical Analysis, Vol.3, John Wiley \& Sons Inc.: New York, 2000.

13. Melo, N. F. S.; Grillo, R.; Rosa, A. H.; Fraceto, L. F.; J. Pharm. Biomed. Anal. 2008, 47, 865.

14. Mishra, A. K.; Gode, K. D.; Analyst 1985, 110, 1373.

15. Morales, A.; Richter, P.; Toral, M. I.; Analyst 1987, 112, 971.

16. Reday, C. S.; Reddy, S. J.; Electroanalysis 1992, 4, 595.

17. Khodari, M.; Mansour, H.; Mersal, G. A. M.; J. Pharm. Biomed. Anal. 1999, 20, 579.

18. Du, J.; Hao, L.; Li, Y. ; Lu, J.; Anal. Chim. Acta 2007, 582, 98.

19. Belal, T. S.; J. Fluoresc. 2008, 18, 771.

20. Tubino, M.; Queiroz, C. A. R; Anal. Chim. Acta 2007, 600, 199.
21. Tubino, M.; Rossi, A. V.; Magalhães, M. E. A.; Anal. Lett. 1997, $30,271$.

22. Lima, L. S.; Weinert, P. L.; Lemos, S. C.; Sequinel, R.; Pezza, H. R.; Pezza, L.; Spectrochim. Acta, Part A 2009, 71, 1999.

23. Weinert, P. L.; Pezza, L.; Pezza, H. R.; J. Braz. Chem. Soc. 2007, 18, 846.

24. Ribeiro, P. R. S.; Pezza, L.; Pezza, H. R.; J. Braz. Chem. Soc. 2006, 17, 674 .

25. Gotardo, M. A.; Gigante, A. C.; Pezza, L.; Pezza, H. R. Talanta 2004, 64, 361.

26. Matias, F. A. A; Vila, M. M. D. C.; Tubino, M.; Sens. Actuators, B 2003, 88, 60 .

27. Matias, F. A. A.; Vila, M. M. D. C.; Tubino, M.; J. Braz. Chem. Soc. 2004, 15, 327.

28. Tubino, M.; Souza, R. L.; Talanta 2006, 68, 776.

29. Eckschlager, K.; Errors, Measurement and Results in Chemical Analysis, Van Nostrand Reinhold Company: London, 1972.

Received: May 8, 2009

Web Release Date: October 29, 2009

FAPESP helped in meeting the publication costs of this article. 